\title{
Fenomena Website Streaming Film di Era Media Baru: Godaan, Perselisihan, dan Kritik
}

\author{
Tangguh Okta Wibowo \\ Universitas Gadjah Mada
}

\begin{abstract}
ABSTRAK
Studi ini mengeksplorasi praktik menonton film melalui website streaming film yang ada di Indonesia dan pola komunikasinya dengan pemerintah dan korporasi. Studi ini menggunakan paradigma sebuah prisma dari Saukko (2003) yang merujuk pada penggunaan 'kristalisasi'. Secara metaforis, kristal tidak hanya merefleksikan cahaya ke luar, yaitu dengan menghadirkan kompleksitas yang menyelimuti website streaming film, tetapi juga melihat perspektif dari dalam. Untuk pengumpulan data, studi ini telah mensortir sebagian besar website streaming film yang ada di Indonesia (melalui mesin pencari Google Indonesia). Perkembangan teknologi Internet di era digital ini telah mentransformasi praktik menonton film yang kini dapat diakses di mana dan kapan pun melalui website streaming film. Selama ini persoalan praktik menonton film secara online dilabeli pemerintah sebagai website penyedia film bajakan dan harus diberantas, tetapi di sisi lain, pemilik website tersebut menyediakan semua film secara online gratis dan dapat dinikmati siapa saja dengan tujuan berbagi. Bagian selanjutnya, fokus dari studi ini adalah analisis ketegangan antara website streaming film yang mendorong hiburan film menjadi gratis di era digital dan regulasi negara dan korporat di tengah 'perang terhadap pembajakan'. Di bagian akhir, studi ini secara kritis juga menyoroti ekonomi politik hadirnya website streaming film dan menggunakan perspektif pembajakan untuk menganalisis website streaming film dibalik motif 'ekonomi berbagi' atas kemunculan website tersebut hingga terbentuknya ekonomi hibrid.
\end{abstract}

Kata-kata Kunci: Berbagi file; ekonomi berbagi; ekonomi politik; pembajakan; website streaming film

\section{The Phenomena of Movie Streaming Websites in New Media Era: Temptation, Disputes, and Critique}

\begin{abstract}
This study explores watching movies practice through streaming websites in Indonesia and communication design with the government and corporation. This study uses the paradigm of a prism from Saukko (2003) which refers to the use of 'crystallization.' Metaphorically, the crystal is not only reflecting light outward (by presenting the complexity that envelops the streaming website of the film), but also exploring the perspective from the inside. For data collection, this study had sorted most of movie streaming websites in Indonesia (through Google search Indonesia). The development of Internet technology in the digital age has transformed this practice. Now, it can be accessed anywhere and anytime through streaming websites. So far, the issue which surrounds this practice is labeled by the government as a website which provides pirated movies and must be wiped off, but on the other hand, the website owners provide all movies online for free and can be enjoyed by any users with the purpose of file sharing. Next section, this study analyzes the tension between streaming websites that encourages the practice of watching movies as entertainment becomes free in the digital era versus the state's regulation and corporate in the middle of 'war on piracy'. At the end, this study critically highlights the political economy of the presence of streaming websites and uses a piracy perspective to analyze streaming website behind the motive of 'economic sharing'over the presence of those website until create a form of hybrid economy.
\end{abstract}

Keywords: Economic sharing; file sharing; political economy; piracy; streaming websites for movies

Korespondensi: Tangguh Okta Wibowo, S.Hum, M.A. Mahasiswa Doktoral Program Studi Kajian Budaya dan Media, Sekolah Pascasarjana, Universitas Gadjah Mada, Jl. Teknika Utara, Pogung, Mlati, Sleman, Yogyakarta.Email: tangguh.o.w@ugm.ac.id 


\section{PENDAHULUAN}

Di era digital, aktivitas menonton film sudah sangat mudah untuk djumpai dalam kehidupan sehari-hari dan dapat dinikmati oleh siapa pun. Hal ini berimbas kepada penggunaan VCD/DVD yang mulai ditinggalkan secara berangsur-angsur, termasuk kehadiran bisnis rental VCD/DVD yang semakin berkurang dan tidak jarang susah dijumpai. Kehadiran film yang kini telah terdigitalisasi membuat film yang dulunya harus menyediakan sebuah player atau alat pemutar VCD/DVD, sekarang dapat dimainkan melalui peralatan komputer/ laptop, bahkan melalui smartphone atau tablet. Perkembangan teknologi Internet juga turut memperluas akses dan membuat sirkulasi file film menjadi semakin tidak terbatas, sebagai contohnya di Indonesia, kehadiran website streaming film yang kini semakin menjamur.

Konsep dibalik website ini adalah siapa pun yang ingin menikmati film tinggal mengaksesnya melalui layar komputer dan terkoneksi Internet, tanpa perlu mendaftar dan bersifat gratis tanpa membayar uang sepeser pun. Lebih detailnya, konsep ini pada umumnya adalah seseorang yang 'bersembunyi' di balik layar komputer untuk mengunduh, baik video, musik, film, atau file digital lain, melintasi batas geografis secara anonim (Wibowo, 2017).

Meskipun demikian, kehadiran website streaming ini juga turut membawa kontroversi. Website streaming film ini turut membuat persoalan yang sensitif di era digital sekarang menjadi semakin kompleks, yaitu terkait label pembajakan digital dan perihal pelanggaran hak cipta. Hal tersebut dikarenakan daftar film yang ditawarkan website tersebut adalah film yang memiliki hak cipta dan mereka tidak memiliki izin dari produser film untuk memberikan akses dalam menampilkan atau menyenangkan konten film di website streaming film.

Di sisi lain, website streaming ini juga berselisih dengan pemerintah. Pada tanggal 18 Agustus 2015, terdapat 22 website streaming film diblokir Kementerian Komunikasi dan Informasi yang bekerja sama dengan Kementerian Hukum dan HAM. Langkah ini dianggap sebagai upaya pemerintah untuk menghentikan website streaming pembajak film, meskipun langkah ini dilakukan tanpa konfirmasi dan peringatan sebelumnya bagi para pemilik website (Zuhra, 2016). Setelah diblokir, jika ada pengunjung yang mengakses website tersebut, maka ia akan diarahkan ke sebuah alamat website berisi konten Internet positif, sebagai upaya pemblokiran website yang mengandung hak cipta.

Studi ini bertujuan untuk mengangkat persoalan pembajakan dengan mengkaji kehadiran website streaming film di Indonesia yang menyediakan beragam film dengan cara streaming dan pola komunikasinya dengan pemerintah. Pembahasan teknologi juga tidak dapat dilepaskan dari praktik menonton film online dan budaya berbagi film secara online (atau disebut peer-to-peer disingkat P2P).

Di bagian selanjutnya, studi ini menggunakan kacamata ekonomi politik pembajakan untuk menyoroti motif 'ekonomi berbagi' dibalik hadirnya website streaming film hingga merujuk terbentuknya ekonomi hibrid merujuk pada pemikiran Lessig dan membahas bagaimana posisi website streaming ini hingga menimbulkan perselisihan dengan regulasi pemerintah dan korporat, karena dianggap sebagai website penyedia film bajakan yang seringkali pembajakan diposisikan sebagai oposisi dari inovasi (Lessig 2004, 2008). Akan tetapi studi ini mencoba melihat dari sudut pandang berbeda.

\section{METODE PENELITIAN}

Penelitianinimengadopsiparadigmasebuah prisma, yaitu pada proses 'kristalisasi,' secara metaforis, kristal tidak hanya merefleksikan cahaya ke luar, tetapi juga membiaskannya ke dalam kristal itu sendiri (Saukko, 2003). Penelitian ini 'sebaiknya' mengedepankan tidak hanya perspektif dari luar, tetapi juga dari dalam untuk menciptakan sebuah kritik dalam melihat sebuah objek penelitian. Karena realitas adalah sesuatu yang cair (Saukko, 2003). Di bagian metode, studi ini membatasi terhadap perdebatan hadirnya website streaming ini dalam konteks teknokultur, yaitu menganalisis interaksi antara teknologi, budaya, regulasi dan ekonomi politik dibalik website streaming film. Untuk pengumpulan data, studi ini telah mensortir sebagian besar website streaming film yang ada di Indonesia (melalui mesin pencari Google Indonesia) yang menawarkan pengunjung dengan leluasa menonton film mana yang akan dimainkan. Untuk analisis data, studi ini menerapkan deskriptif analisis, di mana data 
yang dipaparkan dianalisis mempergunakan teori yang relevan secara cair.

\section{HASIL DAN PEMBAHASAN}

Sebelum membahas lebih lanjut tentang website streaming film, perlu sekiranya studi ini menghadirkan sebuah pembahasan atas posisi film hingga sampai pada bentuk yang sekarang ini di era digital. Untuk berbicara tentang film, maka kita tidak bisa melepaskannya dari bioskop. Sekitar tahun 1990-an, sebagian besar bioskop di Indonesia yang muncul masih memakai sebuah tempat dengan sistem sewa atau menonton sebuah film dengan sistem bioskop misbar (singkatan dari gerimis bubar), sehingga bioskop ini terkendala dengan cuaca dan seringkali berpindah-pindah lokasi penayangannya. Tercatat pada tahun 1920, gedung bioskop permanen pertama kali tercipta. Bioskop Kebondjae adalah bioskop pertama yang menyewa tempat khusus untuk menayangkan filmnya. Selain itu, harga karcis juga menyesuaikan dengan kualitas proyektor dan dibagi menurut sistem kelas. Untuk tanda masuk bioskop selain karcis, penonton akan diberikan libretto (sebuah kertas yang memuat ringkasan film yang ditayangkan, karena film yang diputar pada saat itu merupakan film bisu). Meskipun film bisu, terdapat orkes musik yang berdiri di samping layar proyektor untuk mengiringi film. Orkes ini turut mengiringi sesuai dengan adegan film yang ditampilkan, misalnya film aksi, maka pemain juga akan memainkan musik sesuai dengan nadanya (Tobing, 2017).

Perkembangan bioskop sampai saat ini diakui tidak lepas dari peranan infrastruktur yang semakin membaik dan teknologi yang semakin canggih. Pondasi analog untuk pembuatan sebuah film pun mulai bergeser atau bahkan menunjukkan kecacatannya jika dibandingkan dengan media baru di era digital yang semua prosesnya dari digitisasi (proses konversi semua video/film menjadi bentuk digital/data) dan pembuatan film sudah terdigitalisasi melalui komputer. Dalam melihat hal ini, secara konseptual, menurut Tyron, komputer tidak membawa teknologi baru untuk mengubah teknik persinemaan atau produksi film, tetapi kehadirannya memperluas kemungkinan persebaran dan perkembangan, kemudahan dan kesempurnaan dari produksi dan sirkulasinya di Internet (Tyron, 2013).

Adapun era digital merupakan era yang menggambarkan realitas melalui sebuah film dalam bentuk digital dengan format tinggi, high definition video (Rombes, 2009). Secara harfiah, perbedaan antara analog dan digital sangatlah rumit. Jika analog dikaitkan dengan kuantitas fisik yang dapat dimainkan dan diubah menggunakan sebuah mesin yang mengonversi rekaman tersebut dan dari rangkaian gambar dan suara melalui proses digitisasi. Sedangkan media digital tidak merekam sebuah representasi langsung dari serangkaian proses, tetapi ia merepresentasikan proses sebagai informasi/ data yang diproses dan diciptakan melalui komputer. Sementara Brooker menyebutkan, semua perilaku kita di kehidupan sehari-hari juga bergeser, yaitu secara signifikan adanya perubahan dari analog ke antar muka digital (Brooker, 2010).

Lebih lanjut dikatakan bahwa jika hasil dari bentuk digital dapat dengan mudah untuk disalin/diduplikasi dengan hasil akurasinya 100\% sama dengan file asli (Rombes, 2009). Secara simbolik, replikasi yang sempurna dijanjikan oleh digital. Semuanya adalah hasil salinan, dari sebuah salinan, dan sebuah salinan. Sebuah pengakuan bahwa adanya ketakjuban dan teror dari digital bahwa semua file digital dari musik dan video dapat disalin tanpa adanya pelemahan atau penurunan kualitas dari suara dan gambar akibat reproduksi.

Secara sederhana, film yang dahulunya diperlakukan sebagai barang fisik yang hanya dapat ditayangkan melalui proyektor dan layar besar pada sebuah bioskop, sekarang film telah terdigitalisasi dan semua proses (pembuatan, editing, rendering, dan produksi) menggunakan komputer. Teknologi memberikan keleluasaan bagi penonton dan menghadirkan sebuah kemudahan akses, yaitu mereka tidak perlu lagi pergi ke bioskop untuk menonton sebuah film, tetapi mereka dapat menontonnya menggunakan alat pemutar digital seperti mesin pembaca DVD, laptop, komputer, atau bahkan melalui smartphone.

Pembahasan film di era digital ini menjadi pijakan penting dalam memahami posisi film yang sekarang ini sifatnya sangat cair(seamless), karena teknologi digital mempermudah konten (berbentuk digital) untuk direproduksi dan didistribusikan, karena konten tersebut hanya berbentuk bit (Wibowo, 2015). Peralatan 
digital mengubah mekanisme reproduksi dan pendistribusian konten. Bagaimana informasi teknologi, komunikasi data dan proses teknologi adalah alat untuk memanipulasi, mengorganisasi, mentransmisi, dan menyimpan informasi dalam bentuk digital (Zysman, 2002). Semua proses ini berlangsung dalam hitungan detik untuk menyebarkan/berbagi sebuah file digital dan hasil salinan sama persis dengan file yang dikopi baik melalui website berbagi file (file-sharing).

Posisi ini membawa sebuah kondisi yang sama sekali belum pernah ada di masa sebelumnya, artinya perkembangan teknologi Internet ini bisa dikatakan masih bersifat sementara atau masih terus berkembang. Hingga pada saat memasuki era digital dan Internet, bisa dikatakan teknologi Internet juga turut membuat distribusi konten ini semakin bebas. Hanya dalam sebuah klik, sebuah file atau konten digital di Internet dapat diunduh (download) di layar pribadi melalui laptop atau smartphone. Studi ini mengangkat sebuah fenomena website streaming film yang ada di Indonesia. Karena website streaming film ini memberikan sebuah akses kepada pengunjung website atau dengan kata lain siapa saja yang mengakses website tersebut dapat menikmati film-film yang disajikan sesuai dengan tatanan dan kategori yang rapih. Pengunjung tinggal mengakses film yang ingin ditontonnya.

Kehadiran website streaming film di Indonesia menjadi sebuah pilihan hiburan bagi para penonton yang ingin menonton film secara gratis dengan bebas memilih judul film dan selalu diperbaharui. Beragam film yang ditawarkan berasal dari mancanegara maupun lokal. Sederhananya, pengguna yang ingin memainkan film tinggal menggunakan peralatan digital mereka, seperti laptop/komputer yang terkoneksi Internet untuk membuka sebuah alamat URL website. Lalu, pengguna tinggal mencari film yang hendak ditonton melalui kolom pencarian film atau dapat dipilih melalui kolom kategori berdasar genre, tahun, film serial, umur, sering banyak ditonton, kualitas video, negara, dan indeks judul film.

Daftar film yang dapat diakses oleh pengunjung website berasal dari beragam genre, mulai dari tahun 1920, hingga film yang masih diputar di bioskop sekarang untuk film Hollywood. Di sisi lain, fasilitas yang diberikan oleh website streaming film ini adalah penonton dapat dengan leluasa mengunduh (download) film yang ingin ditontonnya di media penyimpanan online (dinamakan cloud storage). Website-website tersebut memanfaatkan fasilitas media penyimpanan online gratis pihak ketiga, seperti Google Drive, Streamango, Usercloud, Upload.io, Filebebo, dan lainnya. Penonton jika memiliki akses Internet yang cepat/broadband dapat mengunduh film dan menontonnya di layar laptop di lain waktu setelah selesai diunduh.

Proses tersebut nyaris tidak memerlukan perantara fisik, karena semua prosesnya terjadi secara otomatis dari film yang berbentuk data dan diunduh melalui laptop yang terkoneksi Internet. Praktik ini turut memperluas sirkulasi film yang ditawarkan, terlebih lagi penonton tidak perlu untuk mendaftar sebagai member untuk dapat mengunduhnya atau secara anonim. Dengan kata lain, setiap orang yang mengunduh tidak dapat dimonitoring atau ditelusuri yang siapa yang telah mengunduh, dan film apa yang telah diunduh, serta film apa yang telah ditonton secara streaming. Penonton tidak perlu membayar tiket seperti rezim bioskop untuk menonton satu buah film. Penonton yang biasanya sering menonton di bioskop seolah dihadapkan pada pilihan terbatas, tetapi kini penontonlah yang leluasa untuk memainkan film mana yang akan ditonton secara online atau diunduhnya.

Persoalan akses dan batas geografis dapat menghambat penikmat film, terutama bagi penonton yang lokasi bioskop sangat jauh dari tempat tinggal mereka. Dari pengakuan dari sebuah akun di forum Kaskus, yaitu Layarkaca21.com, akun ini mengakui jika tidak semua penonton di Indonesia bisa menikmati film-film di bioskop. Misalnya di pulau Sumatera, penonton yang ingin menonton film di bioskop harus pergi ke kota terlebih dahulu (Lk21.tv, 2017).

Di sisi lain, bahwa pemberitaan penerapan teknologi 4G LTE (sepuluh kali kecepatan 3G dalam mengakses data) melalui media massa online Kompas Tekno penting untuk diberitakan (Gemiharto, 2015). Artinya penerapan Internet dengan kecepatan tinggi merupakan sebuah agenda yang akan terus digalakkan. Terlebih akses Internet dengan koneksi 4G LTE telah mampu diadopsi oleh perangkan smartphone yang beredar saat ini. Di sisi harga, smartphone yang dapat mengadopsi teknologi ini juga 
semakin murah dan mudah di dapat, ditambah lagi sudah menjamurnya teknologi portable wifi dengan kecepatan 4G LTE dijual bebas yang mulai menggeser teknologi modem. Melalui alat portable wifi ini, baik komputer atau smartphone dapat terhubung Internet menggunakan koneksi wifi, sehingga dengan membuat website streaming film, akses informasi di Internet menjadi lebih demokratis dan partisipatoris, karena siapa saja dan secara anonim dapat mengakses website tersebut, baik melalui perangkat komputer atau pun perangkat smartphone.

Dengan demikian, secara politik posisi beberapa individu pemilik website streaming film dapat dilihat jika posisi mereka berpartisipasi dalam sirkulasi 'abu-abu' produk budaya (film). Secara tidak langsung mereka juga turut menegosiasi dan mendestabilisasi model monopoli dari distribusi film di luar struktur kapitalisme, misalnya melalui bioskop dan peredaran DVD original. Dalam kasus musik, Kwong menulis, pembeli menolak jika apa yang dilakukan mereka (membeli VCD bajakan) adalah tindakan yang menyimpang dan mereka menyalahkan harga $C D$ musik yang terlalu tinggi yang dibanderol oleh industri musik (Chiou, Huang, \& Lee, 2005). Menariknya, beberapa konsumen tertarik untuk membeli produk meskipun produk tersebut adalah hasil kopi/salinan (Jain, 2008).

Tulisan ini turut mengangkat keterkaitan yang berjalan berkelidan dengan persoalan pembajakan di era digital. Hal ini dikarenakan secara implisit, praktik yang menyelimuti website streaming film ini tidak dapat dielakkan bahwa keberadaan website streaming film turut menyumbang (artinya bukan satu-satunya faktor dominan) kelanggengan pembajakan media di Internet, sehingga menonton film secara streaming online menjadi budaya menonton film yang 'alamiah' atau 'taken-for-granted' bagi penonton.

Selanjutnya, tulisan ini mencoba menghadirkan pandangan kritis tidak hanya mengeksplorasi budaya menonton film secara streaming, tetapi juga juga mempertimbangkan perselisihan atas persoalan pembajakan media yang juga tidak bisa dilepaskan dan pola komunikasinya dengan pemerintah. Hal ini dikarenakan film-film yang ditawarkan website streaming merupakan film yang memiliki hak cipta.
Ketika masyarakat tumbuh dan melihat Internet sebagai sumber bagi setiap individu yang memberikan keleluasaan setiap individu untuk berbagi, seperti berbagi cinta, berbagi konten, dan berbagi kuota. Mereka menjadi tidak terlalu ketat dalam membedakan apa yang didefinisikan sebagai bentuk konten yang legal dan ilegal. Apa yang hadir sekarang adalah sebagai pengetahuan publik dan kapital budaya/ intelektual seharusnya tersedia bagi semuanya tanpa ada yang mencoba mengaturnya (Ramini \& Marshall, 2014). Adapun hukum atau aturan hak cipta nantinya tidak akan dapat diaplikasikan, karena Internet dan peralatan digital yang semakin canggih berevolusi menjadi layaknya sebuah mesin pengopi yang masif yang dapat digunakan untuk membajak software, video, musik, dan teks dengan menekan tombol keyboard atau klik di tetikus (Shapiro, 1999).

Persoalan yang timbul karena kehadiran websiteinimembuatmasyarakatsepertidiberikan sebuah alternatif untuk mengonsumsi film, yaitu dengan cara streaming atau menonton secara online dan gratis di website-website streaming film. Kemudian, hal ini turut menumbuhkan sebuah budaya baru bagi masyarakat, yaitu menonton film secara online. Hal yang gratis inilah yang menjadikan perdebatan dengan industri konten yang kemudian merangkul pemerintah untuk menegakkan sistem hak cipta. Inilah yang menyebabkan komunikasi antara pemerintah dan korporat 'melawan' kehadiran website streaming film menjadi pihak yang selalu berselisih, karena website streaming film merupakan website penyedia film yang telah dibajak dan melanggar hak cipta, serta disebarkan secara gratis.

Dalam diskusi terhadap persoalan pembajakan, perdebatan akan fokus pada penguatan aparat kepolisian, pelurusan prosedur pengadilan, hukuman kriminal yang ditambah, perluasan pengawasan, dan ukuran hukuman di Internet. Perdebatan ini tidak akan pernah berhenti, karena selalu dibahas bagaimana pendidikan akan membangun sebuah 'budaya properti intelektual' yang kuat kedepannya atau mengedepankan rezim hak cipta. Penguatan akan terus dilakukan seperti razia di jalan, kerja sama antara industri dan pemerintah, dan pelobian kebijakan (Karaganis, 2011). Menurut Kahn dan Kellner, Internet merupakan sebuah arena kontestasi antara dua kubu, yaitu golongan 
kanan/kiri atau dominan/subkultur (Kahn \& Kellner, 2006). Perselisihan ini menampilkan dua kubu yang sedang berselisih, yaitu antara pemerintah, pemegang hak cipta, industri perfilman, dan Asosiasi Produser Film Indonesia (Asprofi) 'melawan' website streaming film yang dilabeli sebagai website pembajak film. Persis ketika website streaming ini mulai marak di tahun 2009 dengan website streaming populer pada masa itu yaitu Ganool.com, tepatnya 18 Agustus 2015, sebanyak 22 website penyedia film bajakan (Lihat tabel 1) diblokir Kementerian Komunikasi dan Informasi yang bekerja sama dengan Kementerian Hukum dan HAM. Langkah ini disebut-sebut sebagai upaya pemerintah untuk 'mematikan' website pembajak film, yaitu dengan dialihkan ke halaman Internet positif untuk menunjukkan jika website yang dikunjungi adalah terlarang atau telah diblokir (Zuhra, 2016).

Meskipun demikian, perselisihan antara kubu kanan (pemerintah dan korporat) seolah menunjukkan sebuah 'perang terhadap pembajakan' melawan website streaming film tidak selesai begitu saja. Karena beberapa hari setelah penutupan 22 website tersebut, pemilik website beralih dari satu domain ke domain lain, misalnya website Ganool.com mengganti domainnya menjadi Ganool.video (sekarang Ganool.se) (Zuhra, 2016). Terhitung sampai Agustus (2016), terdapat sejumlah 108 situs penyedia konten bajakan yang diblokir oleh Kementerian Komunikasi dan Informatika (Zuhra, 2016). Di tabel 1 dapat dilihat jika setelah penutupan 22 website streaming film, jumlah website streaming film serupa hadir kembali, bahkan lebih banyak dari pada daftar website yang telah diblokir pemerintah, yaitu ada sekitar 52 website (beberapa website ini adalah website streaming film telah dipetakan di bulan Juni, tahun 2018, bukan tidak mungkin jumlahnya lebih dari ini atau beberapa diantaranya mungkin telah diblokir setelahnya dan berganti domain website). Rifkin memiliki pendapat yang menarik terkait persoalan ini:

Jika kita bisa menciptakan sebuah mesin yang berisi apa yang kita pikirkan, lalu mesin pencipta itu adalah kita sendiri. Sekarang, mesin tersebut bisa hidup selamanya. Bahkan jika tidak selamanya, ada orang lain yang mengambilnya dan membuat backup (salinan arsip), kemudian dibuka melalui mesin lain akibat mesin sebelumnya rusak (Morse, 2006).

Berdasarkan pendapat Rifkin di atas, ibarat sebuah mesin yang menyimpan file-file digital, ketika suatu saat terjadi pada mesin tersebut (misalnya mesin yang rusak atau ditutup, karena berselisih dengan tuntutan pengadilan), maka bukan tidak mungkin mesin-mesin serupa akan bermunculan akibat hasil kloning atau backup dari mesin sebelumnya. Permasalahan lain yang kerap kali muncul dikarenakan keinginan untuk berbagi file di Internet melalui P2P, siapa pun tidak akan ada yang bisa menghalanginya. Hal serupa juga terjadi pada saat situs Napster ditutup dan tidak dapat diakses, kemudian muncul kompetitornya dengan fasilitas yang diberikan juga kurang lebih sama, seperti Filetopia, Freenet, dan Gnutella menggantikan posisi Napster (Rimmer, 2001).

Dari hasil pemetaan di tabel 1 , tercatat jika website yang telah diblokir, pemilik website dengan segera mengganti domain website yang telah diblokir. Terlebih yang menjadi fokus dalam tabel ini menunjukkan bahwa jumlah website streaming film ini justru semakin bertambah. Penting dicatat jika perselisihan antara kedua kubu (pemilik website streaming film dan pemerintah yang memblokir website tersebut tanpa terjalinnya sebuah komunikasi diantara keduanya), seperti yang diutarakan oleh Lessig, ia memaparkan bagaimana korporasi/industri konten yang merasa adanya ancaman yang datang dari potensi Internet dalam mengubah cara produksi dan distribusi budaya komersial maupun non-komersial; mereka telah bekerjasama dengan pemerintah untuk melindungi konten yang mereka produksi (Lessig, 2004).

Merujuk pada sebuah pandangan bahwa pertarungan tersebut ada dua gagasan: "pembajakan" dan "kepemilikan" (Lessig, 2004). Hal ini (mengakses film melalui website streaming film) tidak hanya terjadi dalam kasus film, tetapi juga dalam kasus video game. Contohnya yaitu mengopi sebuah game PC, secara prinsipnya adalah sederhana, yaitu dengan membeli sebuah kases CD/DVD-RW (burner) dan sebuah software yang mendukung untuk mengopi file tersebut. Lebih kompleks lagi ketika 'pemain besar' yang memiliki kemampuan untuk hacking, mereka kemudian membagikan game tersebut di Internet melalui Bit Torrent atau Kazaa. Hal ini membuat 
Tabel 1 Website Streaming Film di Indonesia

\begin{tabular}{|c|c|c|c|}
\hline \multicolumn{2}{|r|}{ Ditutup Pemerintah } & \multicolumn{2}{|r|}{ Setelah Ditutup Pemerintah } \\
\hline No & Alamat url & No & Alamat url \\
\hline 1 & Ganool.com & 1 & Ganool.se \\
\hline 2 & Nontonmovie.com & 2 & Ganol.movie \\
\hline 3 & Bioskops.com & 3 & Ganool.web.id \\
\hline 4 & Ganool.ca & 4 & Ganool.fun \\
\hline 5 & Kilasan.to & 5 & Ganool.onl \\
\hline 6 & Thepiratebay.se & 6 & Gudangmovies21.co \\
\hline 7 & Downloadfilmbaru.com & 7 & $\mathrm{xx} 1 . \mathrm{me}$ \\
\hline 8 & Ganool.co.id & 8 & indoxxi.us \\
\hline 9 & 21filmcinema.com & 9 & B201.info \\
\hline 10 & Gudangfilm.caa.im & 10 & Watchers.to \\
\hline 11 & Movie76.com & 11 & Thevideo.me \\
\hline 12 & Isohunt.to & 12 & indoxx1.com \\
\hline 13 & Cinemaindo.net & 13 & lele21.info \\
\hline 14 & Bioskop24.net & 14 & lk21.li \\
\hline 15 & Ganool.in & 15 & Dunia21.top \\
\hline 16 & Unduhfilm21.net & 16 & Comotin.info \\
\hline 17 & Bioskopkita.com & 17 & Bioskoponline.org \\
\hline 18 & Downloadfilem.com & 18 & Indomovie.tv \\
\hline 19 & Comotin.net & 19 & Layarcinema.com \\
\hline 20 & Movie2k.ti & 20 & Layarkaca21.us \\
\hline 21 & Unduhmovie.com & 21 & 22cinema.com \\
\hline \multirow[t]{31}{*}{22} & 21 sinema.com & 22 & Downloadmaniak.info \\
\hline & & 23 & Indofiles.id \\
\hline & & 24 & Downloadfilmbaru.xyz \\
\hline & & 25 & Bioskop55.me \\
\hline & & 26 & Movieon21.com \\
\hline & & 27 & Bioskop45.com \\
\hline & & 28 & Bioskop007.me \\
\hline & & 29 & Nontoncinema.org \\
\hline & & 30 & Bioskopfilm21.net \\
\hline & & 31 & Nonton01.com \\
\hline & & 32 & Sobatmovie.com \\
\hline & & 33 & 21boxoffice.com \\
\hline & & 34 & Filmbioskop21.co \\
\hline & & 35 & Movieon21.com \\
\hline & & 36 & Tv21.org \\
\hline & & 37 & Dwa21.com \\
\hline & & 38 & Dramakoreaindo.com \\
\hline & & 39 & 14 movies.com \\
\hline & & 40 & 365 movie.org \\
\hline & & 41 & kebioskop21.com \\
\hline & & 42 & www.layarkaca21.us \\
\hline & & 43 & filmroster.net \\
\hline & & 44 & www.bikinwebs.com \\
\hline & & 45 & lk21tv.com \\
\hline & & 46 & noble-movie.com \\
\hline & & 47 & airfilmsinspections.com \\
\hline & & 48 & halfcockedfilm.com \\
\hline & & 49 & knightstemplarmovie.com \\
\hline & & 50 & templestowepub.com \\
\hline & & 51 & www.shepaper.co \\
\hline & & 52 & bloggingthemovie.com \\
\hline
\end{tabular}


persebarannya ini lebih luas di Internet dan hingga saat ini permasalahan ini belum terselesaikan (Coleman \& Dyer-Witheford, 2007).

Menurut Lundy, kebanyakan apa yang kita alami sekarang adalah tentang perubahan kultural (Rimmer, 2001). Hal ini terjadi karena adanya perselisihan dengan generasi, yaitu saat generasi teknologis mendorong batasanbatasan terhadap kemungkinan yang masuk akal melalui Internet dan lingkungan digital. Di sisi lain, pemimpin-pemimpin industri yang merasa sulit untuk beradaptasi terahadap Internet dan semua kemungkinannya, lalu pemimpin tersebut menggunakan hukum di pengadilan dan parlemen untuk menghalangi dan menutupi perubahan tersebut.

Perspektif yang menarik dari Lessig, yaitu bagaimana melihat budaya bebas ini mendorong untuk memperoleh "manfaat dari produk berhak cipta" tanpa membayar telah menjadi hal yang adiktif di era digital sekarang ini, karena merupakan sebuah cara termudah untuk meraih akses ke beragam jenis konten (Wibowo, 2018). Cleaver berpendapat jika korporat mencoba untuk mengeksplorasi sebuah ruang untuk dapat dikomersialisasikan dan akan dijual ketika mereka mendapat keuntungan, tetapi jika ruang tersebut berbahaya atau mengancam bagi bisnis mereka, maka mereka berusaha untuk menghancurkannya (Simpson, 2004).

Lessig berbicara tentang pembajakan, hukum telah mengatur tentang kepemilikan kreatif atau disebut hak cipta dan persebarannya sebagai hak intelektual (Lessig, 2004). Peran hukum memberikan jaminan kepada pencipta untuk mempunyai kebebasan untuk mengembangkan konten dengan cara baru dan menjamin bahwa pemilik hak cipta mendapatkan kompensasi sesuai dengan konten yang didistribusikan. Perlu diketahui bahwa Internetlah yang turut memberikan provokasi terjadinya perang ini, karena Internet memungkinkan persebaran konten lebih luas dan efisien. Proses berbagi file atau melalui P2P (peer-to-peer) adalah cara berbagi file yang paling efisien dari teknologi-teknologi di Internet. Artinya perubahan tersebut tersirat jika siapa pun bisa "mengambil manfaat secara gratis" karya dari orang lain di Internet.

Hal ini merujuk seperti misalnya mengunduh konten berhak cipta, seperti musik, film, software, dan lainnya. Kemudahan dalam mengakses semua konten ini di Internet, baik secara sadar atau tidak, perilaku ini dikategorikan sebagai pembajakan digital (Wicaksono \& Urumsah, 2017). Meskipun demikian, menurut Arli dan Tjiptono, pembajakan digital ini terjadi tidak hanya di Indonesia, artinya perilaku mengunduh produk digital bajakan ini terjadi dominan di seluruh dunia atau secara gobal, terutamanya di usia remaja dan mahasiswa (Wicaksono \& Urumsah, 2017).

Merujuk pertanyaan kritis dari Lawrence Lessig (seorang visioner hukum siber) mengenai pembajakan digital ini, jika kita menganggapnya sebuah perang, apa efek yang akan ditimbulkan dari perang ini bagi generasi penerus? Apa yang akan perang ini lakukan kepada mereka? Siapakah yang menciptakannya perang ini? Bagaimana mereka berpikir tentang perilaku yang normal (jika mengunduh konten digital di Internet dianggap sebagai pembajakan semata)? Apa artinya kepada sebuah masyarakat ketika sebuah generasi dilahirkan sebagai kriminal?

Posisi hak cipta pasti berlawanan dengan salinan dari yang asli. Menurut Lessig, seharusnya hukum tidak meregulasi salinan/ reproduksi modern, tetapi lebih kepada distribusi ke publik salinan dari produk berhak cipta (Lessig, 2008). Jika hal ini tidak diregulasi ulang, maka setiap budaya dalam konteks digital untuk memproduksi sebuah salinan, sehingga setiap bisnis yang menggunakannya akan berpotensi melanggar regulasi hak cipta. Hukum merupakan salah satu bagian dari permasalahan ini dan bagian terbesarnya adalah masyarakat. Norma dan ekspektasi masyarakat di sekitaran kontrol budaya telah diatur sejak satu abad lalu, tetapi kita sekarang hidup di abad yang sangat berbeda dengan sebelumnya, jadi kita perlu untuk mengatur ulang sebuah norma baru.

Komunikasi kedua kubu berlawanan ini sangatlah rumit untuk diuraikan atau bahkan diselesaikan. Melalui sudut pandang ini, kita dapat melihat jika regulasi/sistem hak cipta tidak diregulasi ulang, maka pola komunikasi yang dapat dilihat adalah tidak adanya komunikasi antara pemerintah dan para pemilik website streaming film. Sebab pemerintah akan selalu menutup akses dan memblokir website streaming film secara langsung, dikarenakan kehadiran website tersebut melanggar sistem hak cipta.

Meskipun komunikasi antara keduanya 
berjalin berlawanan, beberapa saat kemudian website serupa akan muncul kembali. Layaknya sebuah akar tinggal atau rizoma, meskipun tubuh utama dicabut, akan muncul tubuh baru yang menggantikannya dan 'perang' dengan cara ini tidak akan pernah selesai meskipun pemblokiran/ penutupan website-website ini dilakukan kembali. Ibaratnya dengan dingin pemerintah memblokir website streaming film tanpa adanya negosiasi sebelumnya, di satu sisi, pemilik website streaming film juga bersikukuh untuk menghidupkan kembali website yang telah diblokir tersebut.

Tulisan ini menawarkan dua pendekatan yang dapat diaplikasikan dalam menempatkan diri dari perselisihan ini, yaitu pendekatan 'terbuka' dan 'tertutup.' Bagaimana ada kontestasi antara kedua pendekatan ini: pertama, pendekatan terbuka adalah seperti yang Lessig utarakan untuk mengatur ulang norma baru, yaitu perlu adanya regulasi ulang terhadap kondisi pertukaran file digital yang memang benar-benar dimanfaatkan untuk keuntungan semata/berorientasi profit (model ekonomi ini dibahas di bagian selanjutnya) atau dipergunakan murni untuk berbagi file (SaintAmour, 2008).

Kedua adalah pendekatan tertutup, yaitu penguatan kekuasaan dan kontrol melalui aturan ketat untuk mempergunakan file digital yang mengandung hak cipta atau erat kaitannya dengan kepemilikian dan hak kekayaan intelektual untuk memberikan kompensasi kepada pencipta dan untuk mendapatkan keuntungan. Pendekatan tertutup ini erat kaitannya dengan aturan yang bersifat memaksa, seperti pemblokiran langsung 22 website tanpa konfirmasi dari pemerintah dan kemungkinan pemerintah juga akan tetap berusaha memblokir website serupa terus-menerus.

Akan tetapi ada kemungkinan muncul sebuah pertanyaan, apakah yang dilakukan pemerintah dengan memblokir ini tindakan sia-sia? Jawabannya adalah tidak. Karena telah disinggung diawal jika teknologi Internet masih bersifat sementara, artinya akan muncul sebuah inovasi baru dalam pendistribusian konten film dan mungkin saja akan berbeda sama sekali dengan kondisi yang ada pada saat ini.

Di sisi lain, pembajakan juga dapat dikatakan bersifat sementara, karena pembajakan akan selalu mengiringi kemajuan teknologi dan perkembangan Internet yang juga bersifat sementara (Wibowo, 2017). Secara mendasar, kemungkinannya sangat kecil untuk menghentikan secara langsung atau menghilangkan sama sekali praktik berbagi file di Internet. Jika usaha pemberhentian ini tetap digalakkan, maka akan selalu muncul sebuah gerakan yang menciptakan inovasi baru untuk mencoba keluar dari kontrol tersebut (Ozdemirci, 2014).

Lebih lanjut, pembahasan yang lebih menarik yaitu saat menggunakan kerangka berpikir dari Lessig. Ia membagi beberapa tipe ekonomi, yaitu ekonomi komersial: secara umum ekonomi ini merujuk pada uang atau harga sebagai pertukaran. Internet membuka peluang besar bagi bisnis untuk menghasilkan uang dengan cara membuat bisnis yang lama bekerja lebih baik dan memungkinkan adanya bisnis yang tidak mungkin sebelumnya (Lessig, 2008). Internet akan lebih mudah untuk mencari film, karena dengan teknologi cerdas sesuai preferensi dan Internet akan membantu lebih baik untuk mencari apa yang kita inginkan. Sebagai contoh ekonomi komersial ini adalah layanan media streaming seperti Netflix, Iflix, Genflix, Hooq, dan lainnya.

Konsepnya, fasilitas yang diberikan media streaming ini adalah sama dengan yang diberikan oleh website streaming film, akan tetapi perbedaannya terdapat pada penonton harus membayar langganan perbulan untuk menonton film secara online melalui aplikasi yang telah disediakan. Dikarenakan media streaming film ini disediakan oleh industri konten. Oleh sebab itu, kehadiran mereka adalah berada di kubu kanan, atau kubu yang dianggap 'legal' oleh pemerintah, karena memiliki kebijakan dengan perusahaan film dalam membayar royalti perfilm yang dimainkan oleh pelanggannya.

Selanjutnya adalah ekonomi berbagi: yaitu sesuatu yang dipertukarkan bukanlah uang. Misalnya kita meminta seorang teman kita menghabiskan waktu bersama, dan hubungan ini hanyalah pertemanan. Akan tetapi jika kita membayar atas waktu yang dimiliki oleh teman kita, maka hal tersebut bukanlah pertemanan. Posisi uang pada ekonomi berbagi ini adalah tidak tepat. Apa yang dibagi bagi ekonomi berbagi, mereka berbagi bukan semata-mata untuk memberi manfaat bagi orang lain, tetapi semua kategori dari ekonomi berbagi tidak fokus kepada uang. Motivasi bisa bersifat beragam, yaitu misalnya menulis sebuah artikel 
di Wikipedia untuk membantu misi Wikipedia dalam membangun ensiklopedi gratis atau untuk berharap adanya timbal-balik, seperti reputasi yang didapatkan ketika menulis banyak artikel di sebuah forum online.

Berdasarkan tipe ekonomi komersial dan ekonomi berbagi, posisi website streaming film ini berada dalam model ekonomi yang kedua, karena website ini hanya menyediakan akses kepada penonton atas film-film yang telah dikumpulkan, bukan untuk menjual kepada penonton yang harus menarik bayaran perfilm yang ditonton secara streaming. Konsep utamanya adalah berbagi file film secara streaming atau file film tersebut dapat diunduh (download) dengan mudah.

Meskipun demikian, secara kritis muncul sebuah pertanyaan, lalu apa timbal balik yang diperoleh oleh pemilik website streaming film tersebut? Bagaimana website ini bisa bertahan dengan jumlah pengunjung website perharinya? Berapa modal ekonomi yang dibutuhkan untuk menjalankan sebuah website streaming film? Beberapa pertanyaan cukup menggelitik jika website streaming film ini hadir hanya untuk berbagi file film dan mengadvokasi penonton di luar jangkauan bioskop tanpa tendensi apa pun. Pertanyaan tersebut menjembatani kepada sebuah kritik 'ke dalam,' yaitu apa yang sebenarnya pemilik website streaming film dapatkan setelah berbagifile di website tersebut.

Sebenarnya apa yang bisa dipetik dari kedua model ekonomi dari Lessig merujuk kepada model ekonomi ketiga, yaitu ekonomi hibrid. Maksud dari model ekonomi ini adalah percampuran antara komersial dan berbagi. Hibrid disini merupakan entitas komersial yang bertujuan meningkatkan nilai dari ekonomi berbagi, atau kebalikannya ekonomi berbagi membangun entitas komersial untuk mendukung tujuan berbagi (Lessig, 2008).

Kasus website streaming film sangat menarik untuk melihatnya sebagai gerakan perlawanan terhadap kubu kanan (pemerintah dan korporat) yang dominan, tetapi di satu sisi, tulisan ini juga turut mengulas motif dibalik ekonomi berbagi. Dari kerangka teoritis tiga model ekonomi dari Lessig, website ini mengaplikasikan model ekonomi hibrid. Meskipun demikian, perlu dibangun argumen untuk mendiskusikan sampai pada tahap kategori ini (Lessig, 2008).

Label 'membajak (pirate)' dipergunakan komunitas berbagi file untuk melabeli aktivitas yang mereka anggap menyimpang, jadi bukan label bagi komunitas berbagi yang memiliki tujuan berbagi dan bukan berorientasi profit, karena mereka hanya bertujuan berbagi tanpa mengharapkan kompensasi uang atas apa yang dibagi. Aktivitas yang mereka lakukan adalah untuk memfasilitasi film perihal promosi, oleh karena itu mereka membedakan diri dari aktivitas yang tidak memiliki moral, ilegal, dan tidak dapat dipertahankan untuk mendapatkan keuntungan ekonomi dari pembajakan. Lebih lanjut, individu membedakan dirinya dengan dari label ilegal dan konotasi tidak etis dari istilah 'pembajakan' untuk mendefinisikan sesuatu praktik di luar berbagifile, yaitu menjual barang fisik yang berorientasi mendapatkan keuntungan (Crisp, 2014).

Melalui perspektif ini, terlalu dini jika aktivitas berbagi file ini juga dilihat melulu sebagai pembajakan semata dan disamakan dengan pembajakan yang memang dilakukan untuk tujuan profit atas penjualan per judul film yang produksi dalam sebuah DVD dan diperjualbelikan (jika dilihat dari model ekonomi komersial). Mengacu pada sebuah penelitian (Anshari, 2014), dikatakan bahwa proses digitalisasi media ini bersifat sangat cair, dan tidak memerlukan perantara teknologi fisik, bersifat global, dan sulit untuk dilabeli dengan nilai ekonomi dalam konteks komoditas klasik.

Untuk menghindari pelabelan sebagai pembajakan, sebagian besar website memiliki struktur yang serupa, yaitu mereka berstrategi dengan menampilkan sebuah pernyataan (disclaimer) di laman website mereka bahwa film-film yang ditampilkan di website streaming film bukanlah milik dari website tersebut, melainkan diperoleh dari website pencarian di Internet, seperti Google atau media penyimpanan online pihak ketiga. Mereka hanya menyematkan sebuah pemutar film (player) untuk dapat memainkan file film di website mereka.

Pertanyaan yang muncul kemudian adalah bagaimana posisi website streaming film ini? Kehadiran website streaming film memberikan akses kepada penonton untuk menonton film secara tidak terbatas, baik untuk streaming atau diunduh (download) file film tersebut. Website ini tidak mempermasalahkan penonton yang bertindak sebagai 'penumpang gratis/free loaders' yang menyedot sumber daya online 
Tabel 2 Statistik Pengunjung Website Streaming Film LK21.TV

\begin{tabular}{|c|c|c|c|}
\hline Bulan & Tahun & Rata-rata pengunjung per hari & Peningkatan (dalam persen per tahun) \\
\hline November & 2015 & 1.723 & - \\
\hline Januari & 2016 & 43.821 & $0,5 \%$ \\
\hline Desember & & 1.536 .826 & $18,1 \%$ \\
\hline Januari & 2017 & 1.571 .319 & $18,1 \%$ \\
\hline April & & 1.954 .844 & $22,5 \%$ \\
\hline
\end{tabular}

Sumber data: disarikan dari website Histats khusus Lk21.tv (Histats, 2017)

yang disediakan oleh website tersebut, seperti mengunduh film, bandwidth, dan server yang menampung ratusan hingga jutaan pengunjung per harinya. Misalnya salah satu website streaming film yang populer atau salah satu yang paling banyak pengunjung per hari diantara lainnya, yaitu website LK21.tv yang didirikan di bulan November 2015 (sekarang beralih domain menjadi LK21.pw, karena domain sebelumnya diblokir pemerintah). Statistiknya dapat dilihat di tabel 2.

Lalu, secara implisit apa yang dipertahankan website streaming film ini. Apakah hanya mengaplikasikan ekonomi berbagi? Ternyata saat penonton ingin menikmati film di website streaming film, penonton harus berkompromi dengan melihat iklan-iklan yang dipajang di setiap halaman website yang dibuka oleh penonton. Mereka (website streaming film) bertahan dengan melakukan komersialisasi film-film yang disediakan dan selama ini disokong oleh iklan. Sebuah website streaming film dapat menampilkan iklan dari 6 hingga 19 iklan model banner yang ditampilkan dalam satu halaman penuh website (jika diakses melalui layar komputer). Terkadang beberapa website streaming film menempatkan iklan yang sifatnya pop-up (membuka halaman website baru secara otomatis).

Menurut kesaksian salah satu pemilik website streaming film, ia menyadari jika kehadiran iklan ini mengganggu para pengunjung ketika menonton. Bahkan pemilik sendiri juga merasa dilema dengan keberadaan iklan tersebut dan sebenarnya tidak ingin menampilkan iklan-iklan tersebut. Akan tetapi tidak ada pengiklan yang mau beriklan di website streaming film selain iklan judi, karena website tersebut berbau pembajakan, sehingga seakan tidak ada pilihan bagi mereka untuk menampilkan iklan-iklan tersebut di website mereka (Kaskus, 2017).

Dari data tabel 2, jumlah penonton/ pengunjung website yang mencapai 1,9 juta per hari di bulan April 2017 dengan menampilkan 19 iklan dan rata-rata iklan membayar 100 ribu per hari (dari pengakuan akun pemilik Lk21.tv di Kaskus, 2017). Sehingga perkiraan pendapatan website per bulan adalah 57 juta rupiah. Pendapatan dari iklan ini belum dikurangi dengan biaya produksi misalnya karyawan, hosting, domain, dan server. Pendapat tersebut hanyalah bersifat perkiraan pendapatan website streaming film, Lk21.tv. Kemungkinan pendapatan ini bisa berkisar diatas 57 juta rupiah per bulan atau dibawahnya, serta pendapatan website streaming film lainnya juga bervariasi, tergantung dengan jumlah pengunjung per bulan.

Kasus lain, Solan, salah seorang pemilik webiste streaming film, mengaku bahwa modal untuk membuat sebuah website streaming film sekitar \$100 atau sekitar Rp 1,3 juta per tahun sebagai biaya untuk domain dan hosting. Dari bisnis ini, sebuah perkiraan seorang pemilik website abcd bisa mendapat $\$ 100$ per hari. Dalam sebulan, pemilik website dapat menghasilkan sekitar Rp 39 juta. Hal ini dikarenakan Solan memperlakukan bisnis ini hanya sampingan. Jika ia menekuni website ini, pendapatan yang didapatnya bisa dua kali lipat (Zuhra, 2016). Inilah yang diperoleh website streaming film dari model ekonomi berbagi.

Secara tersirat, website streaming film tidak mengacu pada model ekonomi komersial yang berorientasi profit dengan menjual per judul film atau pertukaran dengan uang. Akan tetapi melalui sistem online. Daftar hadir pengunjung website terekam dan tercatat dalam statistik pengunjung. Data ini yang kemudian dikomodifikasi oleh pemilik website untuk menjualnya kepada pengiklan. Pertukaran 
yang dilakukan memang bukanlah pertukaran uang secara langsung, tetapi melalui konversi dari statistik data pengunjung menjadi bannerbanner iklan yang ditampilkan di website dan per banner dihargai dengan uang. Secara implisit, sebuah entitas berbagi diusahakan untuk meningkatkan berbagifile dan pengunjung untuk meningkatkan entitas komersial secara tidak langsung. Faktanya, website streaming film menerapkan model ekonomi hibrid, yaitu gabungan dari ekonomi berbagi dan ekonomi komersial. Dengan kata lain, website streaming film ini selain melakukan sebuah perlawanan terhadap distribusi film yang di dominasi oleh kapitalisme, di sisi lain, mereka memiliki motif tersendiri, yaitu memperoleh penghasilan dari aplikasi model ekonomi hibrid ini.

\section{SIMPULAN}

Studi ini mengkaji kompleksitas praktik menonton film melalui website streaming film Indonesia. Rekomendasi yang ditawarkan adalah sebaiknya melihat fenomena ini tidak dari posisi biner, benar dan salah, tetapi melihat kompleksitas di dalamnya. Bisa dikatakan jika file digital dari sebuah film berperan dalam membuat sirkulasinya menjadi lebih cair, dan proses reproduksi dan transmisi file bisa terjadi dalam hitungan detik. Oleh karena itu, film berbentuk digital ini dapat dengan mudah disebarluaskan secara massal. Pada hasil dan pembahasan, kehadiran website streaming film dapat dilihat sebagai sebuah praktik perlawanan, yaitu berusaha untuk menegosiasi dan mendestabilisasi model monopoli dari distribusi film di luar struktur bioskop.

Selanjutnya, selalu terdapat sebuah perselisihan antara kedua kubu, website streaming film (kiri) dan pemerintah dan industri konten (kanan). Perselisihan ini rumit untuk diuraikan atau bahkan diselesaikan. Perselisihan antara pemerintah dan korporat 'melawan' website streaming film semakin kompleks, yaitu dengan hadirnya beberapa media streaming 'legal' dan berbayar dengan sistem langganan per bulan. Terakhir, sebuah kritik juga dilontarkan kepada website streaming film dibalik model ekonomi berbagi (ekonomi hibrid) yang diaplikasikannya, website streaming film juga menghasilkan uang, yaitu mengedepakan model ekonomi berbagi untuk membangun entitas komersial yang mendukung tujuan berbagi file film.

\section{DAFTAR PUSTAKA}

Anshari, I. N. (2014). All you can copy: rekomodifikasi dalam budaya mengopi video di warnet. dalam nazaruddin, muzayin (ed.), konferensi kajian komunikasi, budaya, dan media: membayangkan indonesia baru (hal. 548-559). Yogyakarta: Program Studi Ilmu komunikasi UII.

Brooker, W. (2010). 'Now you're thinking with portals' media training for a digital world. International Journal Of Cultural Studies, 13(6):553-573.

Chiou, J., Huang, C., \& Lee, H. (2005). The antecedents of music piracy attitudes and intentions. Journal of Business Ethics, 57:161-174.

Coleman, S. \& Dyer-Witheford, N. (2007). Playing on the digital commons: collectivities, capital and contestation in videogame culture. Media, Culture \& Society, 29(6):934-953.

Crisp, V. (2014). To name a thief: constructing the deviant pirate. dalam piracy: leakages from modernity. Diedit oleh Martin Fredriksson dan James Arvanitakis, California: Litwin Books.

Gemiharto, I. (2015). Teknologi 4g-lte dan tantangan konvergensi media di indonesia. Jurnal Kajian Komunikasi, 3(2):212-220.

Histats. (2017). Statistik lk21.tv. Diakses dari http://www.histats.com/ viewstats/?SID=3232862.

Jain, S. (2008). Digital piracy: a competitive analysis. Marketing Science, 27(4):610616.

Kahn, R. \& Kellner, D. M. (2006). "Oppositional politics and the Internet: a critical reconstructive approach." Dalam Meenakshi Gigi Durham dan Douglas (editor). Media and Cultural Studies. London: Blackwell.

Karaganis, J. (2011). Rethinking piracy. dalam media piracy in emerging economies. Diedit oleh Joe Karaganis. Amerika: Social Science Research Council.

Lessig, L. (2004). Budaya bebas: bagaimana media besar memakai teknologi dan hukum untuk membatasi budaya dan mengontrol kreativitas. Diterjemahkan oleh Brigitta 
Isabella dkk, Yogyakarta: Kunci Cultural Studies Center.

Lessig, L. (2008). Remix: making art and commerce thrive in the hybrid economy, London: The Penguin Press.

Kaskus. (2017). Berapa kira-kira pendapatan situs layarkaca21. Kaskus. Diakses dari https://www.kaskus.co.id/ thread/587ba3b4a09a3961478b4567/ berapa-kira-kira-pendapatan-situslayarkaca21/.

Morse, M. (2006). What do cyborgs eat? Oral logic in an information society. Dalam Cybercultures: Critical Concepts in Media and Cultural Studies. Volume IV. Diedit oleh David Bell. USA: Routledge.

Ozdemirci, E. G. (2014). Bit Torrent: stealing or sharing culture? A discussion of the pirate bay case and the documentaries 'steal this film' i \& ii. Dalam Piracy: Leakages from Modernity. Editor: Martin Fredriksson dan James Arvanitakis, California: Litwin Books.

Ramini, F. \& Marshall, J. (2014). Piracy is normal, piracy is boring: systemic disruption as everyday life. Dalam Piracy: Leakages from Modernity. Editor: Martin Fredriksson dan James Arvanitakis, California: Litwin Books.

Rimmer, M. (2001). Napster: infinite digital jukebox or pirate bazaar? Online. Queensland University of Technology. Halaman 27-38. Diunduh dari http://works. bepress.com/matthew rimmer/38/.

Rombes, N. (2009). Cinema in the digital age. New York: Columbia University Press.

Saint-Amour, P. K. (2008). Review: copyright wrongs: when technology makes an illegal act easy, should the lawmake that act legal? The American Scholar, 77(4):128-131.

Saukko, P. (2003). Doing research in cultural studies: an introduction to classical and new methodological approaches. London:
Sage Publications.

Shapiro, A. L. (1999). The Internet. Foreign Policy, 115:14-27.

Simpson, S. (2004). Explaining the commercialization of the Internet. Information, Communication \& Society, 7(1):50-68.

Tobing, H. (2017). Secarik sejarah nonton film bioskop tempo dulu. Diakses dari http:// www.wanita.me/culture/sejarah-bioskop/.

Tyron, C. (2013). On-demand culture: digital delivery and the future of movies. New Brunswick: Rutgers University Press.

Wibowo, T. O.(2015). Studi prosumption e-book dalam bingkai sirkuit budaya (fenomena e-book gratis dalam situs membaca cepat. Com). Tesis. Sekolah Pascasarjana UGM: Program Studi Kajian Budaya dan Media.

Wibowo, T. O. (2017). Kompleksitas pembajakan konten di era digital [resensi dari buku piracy: leakages from modernity]. Jurnal Kawistara, 7(2).

Wibowo, T. O. (2018). Ledakan kreativitas dan kontrol hukum di era Internet [resensi dari buku budaya bebas: bagaimana media besar memakai teknologi dan hukum untuk membatasi budaya dan mengontrol kreativitas]. Jurnal Kawistara, 8(2).

Wicaksono, A. P. \& Urumsah, D. (2017). Perilaku pembajakan produk digital: cerita dari mahasiswa di yogyakarta. Jurnal Aplikasi Bisnis, 17(1):22-42.

Zuhra, W. U. N. (2016). Situs pembajak film, patah tumbuh hilang berganti. Diakses dari https://tirto.id/situs-pembajak-film-patahtumbuh-hilang-berganti-GsS.

Zuhra, W. U. N. (2016). Untung besar situs pembajak. Diakses dari https://tirto.id/ untung-besar-situs-pembajak-bwwb.

Zysman, J. (2002). Production in a digital era: commodity or strategic weapon? working paper 147. BRIE. <http://brie.berkeley. edu/>. 